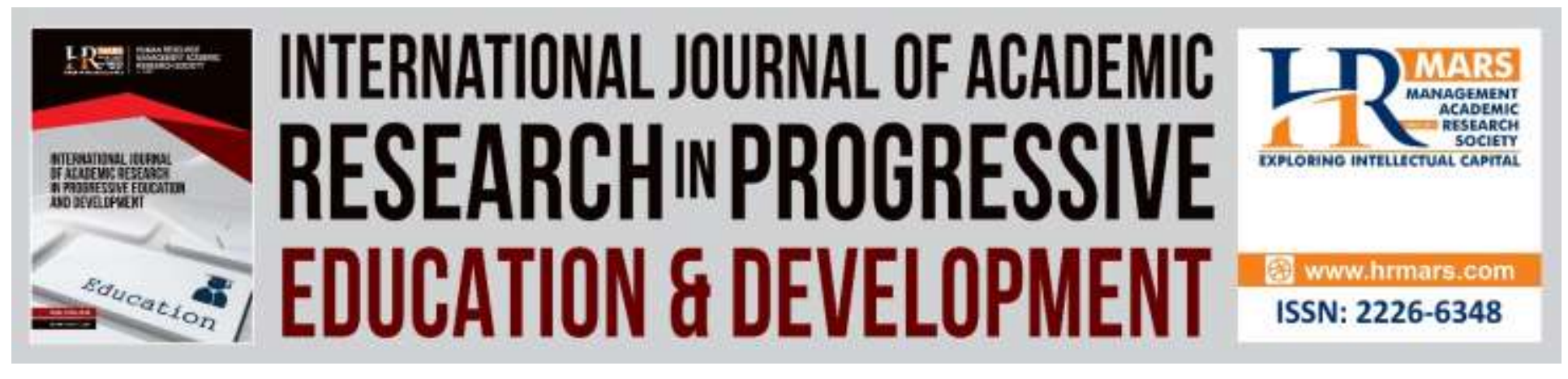

\title{
Juvenile Delinquent Pupils' Perceptions on the Teaching of Islamic Education: A Preliminary Study
}

Asmawati Suhid, Fathiyah Mohd Fakhruddin, Lukman Abdul Mutalib, Abd. Muhsin Ahmad

To Link this Article: http://dx.doi.org/10.6007/IJARPED/v8-i4/6534

DOI: $10.6007 /$ IJARPED/v8-i4/6534

Received: 22 August 2019, Revised: 21 September 2019, Accepted: 26 October 2019

Published Online: 09 November 2019

In-Text Citation: (Suhid, Fakhruddin, Mutalib, \& Ahmad, 2019)

To Cite this Article: Suhid, A., Fakhruddin, F. M., Mutalib, L. A., \& Ahmad, A. M. (2019). Juvenile Delinquent Pupils' Perceptions on the Teaching of Islamic Education: A Preliminary Study. International Journal of Academic Research in Prorgessive Education and Development, 8(4), 340-354.

\section{Copyright: (C) 2019 The Author(s)}

Published by Human Resource Management Academic Research Society (www.hrmars.com)

This article is published under the Creative Commons Attribution (CC BY 4.0) license. Anyone may reproduce, distribute, translate and create derivative works of this article (for both commercial and non-commercial purposes), subject to full attribution to the original publication and authors. The full terms of this license may be seen at: http://creativecommons.org/licences/by/4.0/legalcode

\section{Vol. 8(4) 2019, Pg. 340 - 354}




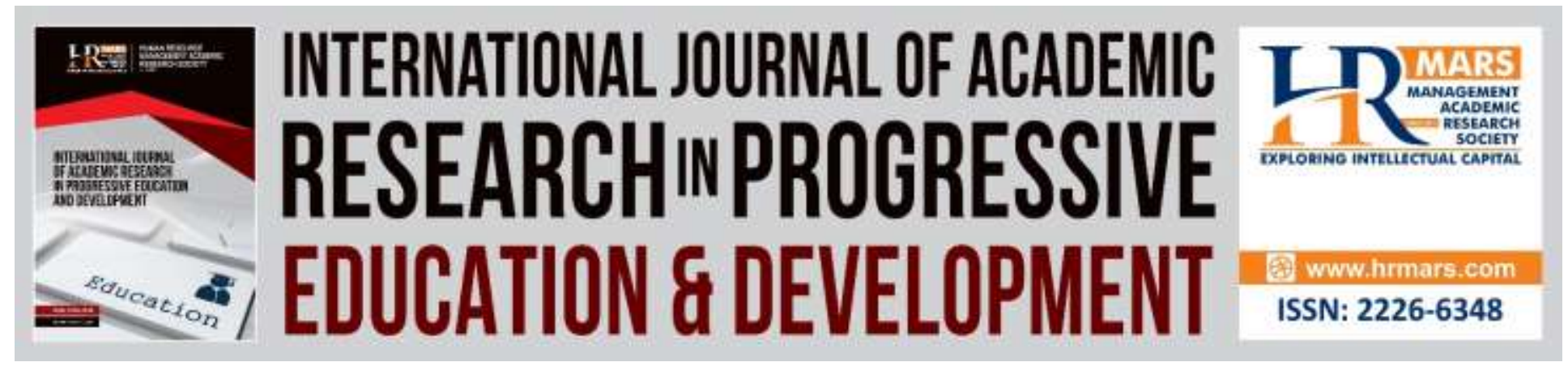

\title{
Juvenile Delinquent Pupils' Perceptions on the Teaching of Islamic Education: A Preliminary Study
}

\author{
Asmawati Suhid, Fathiyah Mohd Fakhruddin \\ Faculty of Educational Studies, University Putra Malaysia, Selangor Darul Ehsan, Malaysia \\ Lukman Abdul Mutalib \\ Faculty of Syariah and Law, University Sains Islam Malaysia, Malaysia
}

Abd. Muhsin Ahmad

Faculty of Law, University of Malaya, Malaysia

\begin{abstract}
The Islamic Education subject is compulsory for all Muslim pupils in Malaysia. Based on the concept of 'Education for All', pupils in the Integrity Schools in Malaysia are also given access to Islamic Education to ensure they are not neglected in the national education development. This is clearly stated in the National Education Philosophy. Therefore, as Malaysian citizens, the delinquent pupils have the right for a comprehensive education. Formal education in Integrity Schools for juvenile delinquents was established in 2008. The pupils are taught Islamic Education, similar to that taught within the national education system. Despite the fact the pupils are regarded as delinquents, they must still be taught and nurtured with Islamic values and morals so they can grow to become responsible individuals in the future. They are the generation that will inherit and shade the colours of the future society. Henceforth, this research seeks to study the perceptions of pupils from the Integrity Schools with regard to Islamic Education, particularly their interests towards it, and the impact it would have on how they practise Islamic values in their lives.
\end{abstract}

Keywords: Islamic Education, Integrity School, Islamic Values, Moral Values

\section{Introduction}

Islam is ad Din, Syumul (universal) and hence is a blessing to the Universe. Al Quran and the Hadith of the Prophet PBUH provide guidance for the lives of mankind as a whole. As long as mankind holds on to these two resources, their lives will not go astray on this earth and they will succeed in the Hereafter. As Rasulullah PBUH has stated: 
INTERNATIONAL JOURNAL OF ACADEMIC RESEARCH IN PROGRESSIVE EDUCATION AND DEVELOPMENT

Vol. 8, No. 4, 2019, E-ISSN: 2226-6348 @ 2019 HRMARS

"I leave behind me two things, the Qur'an and my example, the sunnah, and if you follow these you will never go astray."

Indeed, ad Dinul Islam was sent down by Allah SWT equipped with all the laws and the way of life as guidance for mankind. Laws and the way of life determined by Allah SWT are in harmony with human nature, therefore it is befitting to be practised, regardless of time or era, by any race or nation. (Suhid, 2009)

Therefore, education according to Islam must always be guided by these two resources namely Al Quran and Hadith, whether they are for curriculum and co-curriculum, methods of teaching, the roles and characteristics of a teacher, the administration, management and development of the pupil. However, the discussions here will focus on the agenda of education in developing and producing individuals who are imbued with a balanced and harmonious character. This is so, because the function of education should not only focus on national development and unity as well as the production of human resources, but, should also focus on the development of the individual as a holistic and balanced person, in terms of his physical, emotional, spiritual, intellectual and also social capabilities.

\section{Moral (Akhlak) Education under the Education System in Malaysia}

Drastic changes occurred in the National Education System when the Education Act 1961 (based on the Razak Report 1956 and the Talib Report 1960) included Islamic Education as one of the subjects in the government schools' curriculum. Furthermore, the importance of Islamic Education in government schools could be seen when it was officially included in school timetables and became compulsory for all Muslim pupils in 1962. Pupils were later asked to sit for examination on the Islamic Education subject.

"Considering the importance of the subject on Islamic Education, it is recommended that all Muslim pupils must not only attend classes on the subject but it is also compulsory upon them to sit for the public examination." (Item 126.1)

(Committee for the Study of the Implementation of the Education Policy 1979)

Islam as ad Din and is Syumul has also provided a clear and precise conceptual framework on Islamic manners and morals. The framework is a revelation from Allah SWT, the Creator of the Universe. Therefore, for the Muslims, resources such as Al Quran, Hadith and ljtihad provide a comprehensive guidance for the development of character, which covers all aspects of human life in this world and the Hereafter. Every moral question would have an answer and would have a it definitely solution. According to Hussin (2010), the result of the induction of worldly oriented moral values would lead to an improvement in knowledge, intellect and the quality of an individual. It would also lead to a community that is harmonious and connected that would extend to the nation as a whole. Besides, a community that lives a life of peace and harmony, believing in the certainty of the Hereafter, would be blessed by Allah SWT in their daily lives. 
Thus, Islamic Education is made a compulsory subject to be taught at both primary and secondary schools aimed at producing individuals who would be righteous, faithful, abiding and of moral character. Therefore, Islamic Education must be taught as the subject of ad-Din, not merely to transmit the knowledge and skills but to be practised and fully appreciated by every Muslim individual who has faith in Allah SWT. Based on this understanding, the role of a teacher of Islamic Education is not only to transmit information to the pupils, but also extends to the role of producing balanced and harmonious khalifatullah.

The aspect that is given emphasis in the curriculum of Islamic Education is akhlak or moral education. This is in line with the desire to produce pupils who are educated, competent and honourable as stated in the National Education Philosophy:

Education in Malaysia is an on-going effort towards further developing the potential of individuals in a holistic and integrated manner, so as to produce individuals who are intellectually, spiritually, emotionally and physically balanced and harmonious, based on a firm belief in and devotion to God. Such an effort is designed to produce Malaysian citizens who are knowledgeable and competent, who possess high moral standards, and who are responsible and capable of achieving high level of personal well-being as well as being able to contribute to the harmony and betterment of the family, the society and the nation at large.

(Curriculum Development Centre, the Ministry of Education Malaysia, 1988)

This philosophical statement clearly describes the aim and aspiration of education in Malaysia, which is to produce individuals who are noble and are therefore, also good citizens. As stated by Suhid (2005) through Wan Mohd Zahid, in order to achieve the objectives and the National Education Philosophy, education must first be based on moral values. This was supported by Rashid (2001), who stressed moral values must be made core values and applied in the school curriculum as well as every form of education.

The shaping of noble character and behaviour is the main aim of Islamic Education. Akhlak or Moral Education in secondary schools is the continuation of what had been taught in the New Curriculum for the Primary School (KBSR) level, and in the Integrated Curriculum for Secondary Schools (KBSM), known as "The Manner and Way of Life in Islam". Furthermore, the status of Akhlak education was further elevated when 'Islamic Morality Education' was introduced in 1998. PAI was later replaced with 'Islamic Etiquette and Morality' after reviews of the Islamic Education curriculum was carried out in 2000.

\section{The Moral Practices of Pupils}

One's character is a reflection of one's faith. Character is an aspect which gives a man his values. A person who achieves excellence intellectually but is not morally imbued, has no values. The same would apply to a pupil; academic excellence would have no meaning if he does not act and live a moral life. 
As discussed earlier, Islamic Education is a subject which specifically emphasises on aspects of the moral development of an individual (Mokthar et.al, 2011). The prophetic objective of Prophet Muhammad PBUH, for the whole of mankind, included aspects of moral development of the individual, together with faith, worship and knowledge. Allah SWT in Chapter AI Qalam, Verse 4 states:

\section{"And indeed, you are of a great moral character..."}

This is reflective of the objectives of Islamic Education which is to produce individuals who possess a comprehensive and balanced character and who are able to attain happiness in this world and the Hereafter. In fact, the excellence and beauty of Islamic Education lie in its emphasis on faith, worship and morals which need to be tied up together into a knot. Moreover, teachers play an important role in order to ensure the effectiveness of the teaching and learning process towards the success of the schools (Suhid et.al, 2014).

However, what are commonly reported by the media are the moral problems among pupils, ranging from meaner cases to more serious crimes. An example could be seen in the report in the newspaper by the Deputy Minister of Education, Datuk Wee Kah Siong, on $28^{\text {th }}$ December 2010 (based on the Ministry's records in the year of 2010) as many as 111,484 pupils or 72,557 secondary school pupils and 38,927 primary school pupils had been found to commit various disciplinary wrong doings. Even though the total was only $3 \%$ out of the whole pupil population, the number cannot be under estimated. Disciplinary wrong doings in the country, especially on the issue of school truancy, should be given serious attention. This is because school truancy has been recognized as one of the main reasons why pupils later get involved in various negative activities such as drug abuse, alcoholism, thugs, free sex and gambling.

The National Anti-Drug Agency, which comes under the Ministry of Home Affairs, on the other hand, reported for the month of September 2011, there was a decrease in the number of drug addicts from January till September 2011, which was 8,892 compared to the number of drug addicts during the same duration in the year of 2010, which was 18,387, indicating a decrease of $51.64 \%$. Nonetheless, when the number observed was based on ethnicity, it is obvious that Malay drug addicts recorded the highest number, which is 6,951 or $78.21 \%$ out of the whole total number of drug addicts found. This number gives rise to concerns that caused sadness and disappointment and even worry when the figure was said to represent $0.08 \%$ of the Malay society between the ages of 15 until 64. When reviewed according to age group, teenagers between the ages of 13 and 18 recorded as many as 406 or $4.59 \%$. Even though the percentage of drug addicts among teenagers was not high, but if it is unchecked it will contribute to the number of addicts from the youth group. From January until September 2010, it was recorded a total of 6,910 (78.19\%) youths aged 19 to 30 years were drug addicts and the number may increase if serious action is not taken to deter drug addict cases among the teenagers.

Research by Musliha Salma, et.al (2011) suggested teachers, curriculum and other parties involved must contribute to the development of the pupils' overall character, not excluding the 
moral aspects as well. The development must be based on self-consciousness which is based on the development of spirituality. This clearly proves that Islam and Islamic Religious Education put faith as a basis for developing an individual who is balanced and whole. Historical proof also shows that the process of propagating $D a^{\prime} w a h$ by the Prophet was done by propagating faith first. The process of changing the Arab society's Syirik actions to those of Tauhid undoubtedly was able to build the spiritual element and subsequently developed a pleasing personality.

The moral actions, specifically, among the pupils have to be consolidated and strengthened to deter the increase in disciplinary problems and crime. Henceforth, the teaching of Islamic Education can be seen to play an important role by strengthening the pupils' morals. This is in line with Islam as a way of life which prioritizes Islamic clothing. Islam is not a constricted religion which only prioritizes ritual acts. Islam is based on strong a faith which affects the performance of ibadah and the appreciation of values in the daily life.

\section{Studies on Pupil's Interest in Islamic Education}

Interest according to the dictionary means the desire, fondness or inclination towards something. It is a personal trait and very much related to character. Basically it is synonymous with motivation which is a form of inclination or an inner drive experienced by an individual to choose or to do something (Nazar, 2005). The difference is motivation is an interest on a bigger scale.

Interest is very important to a person. The combination of interest and character could form prejudice. Other than that, it also influences a person's attitude and way of making decisions (Chaplin, 1985). In the learning context, interest is a prerequisite to the process of teaching and learning which is affective because it succeeds in making a learning environment more creative and cheerful. Furthermore, it also helps the pupils enhance their academic achievement. In one research by Zulkarnain, et.al (2011) entitled "The Relationship between Interest, Attitude and Pupils' Achievement" in CC301-Quantitative Measurement Course showed pupils with high level of interests had more positive attitude. Pearson's Correlation test also showed interest had a significant relationship with achievement in that particular subject.

In Islam, the issue of interest has become one of the main elements to succeed in seeking knowledge. Imam al-Syafi'ie said in his poem:

"Dear Brothers! Knowledge will not be attained except with 6 things. I will explain to you in detail, first, there is intelligence, second is desire, third is passion, fourth is sufficient material, fifth is a close relationship with the teacher and sixth is a continuous of istiqamah"( Muhammad: 1986).

Rasulullah PBUH always emphasised on the aspect of interest and motivation in the process of educating. Interests and motivation were digested in the educational process starting from childhood until adulthood. Sometimes Rasulullah PBUH instilled these traits by rewarding and at other times by praising, and would rarely insult or slander. In the Quran, the aspect of interest was put next to the word $a l-H u b b$ which is love or like. Allah clearly states that: 
"Say [O Prophet]: If you love God, follow me, [and] God will love you and forgive your sins, for God is much-forgiving, a dispenser of grace."

(Chapter Ali Imran 3:31)

Allah SWT explains if we really love Allah, hence the love will be tied to obedience to Rasulullah PBUH. In other words, love, like and passion motivate us do things. If we truly love Allah SWT, we will be motivated to obey His laws.

There are a few researches done with regard to the pupils' interests in Islamic Education. Research done by Khadijah Alav, et.al (2012) entitled "A Brilliant Islamic Education Teachers' Social and Emotional Intelligence in Improving Pupil Achievement" showed how a teacher with characteristics of excellent character and personality became the role model to pupils and other teachers. The findings also showed in order to attract the pupils' interests, a teacher must understand the emotional background and academic reputation especially the problematic pupils. One of the methods used to handle problematic pupils are through love and affections.

Interest as has been discussed is an inner trait which exists in a person. However it does not necessarily exist naturally. Interest can also be influenced by external factors and can be developed. This coincides with the opinion of Mohamed (2009) who found methods of stimulation gave a fun effect as well as attracted the pupils' interests to remember and understand well what was taught. This is in line with the concept of $D a^{\prime} w a h$ in Islam where Da'wah bi al-Hal is more effective than Da'wah bi al-Maqal which is ideal for the human nature who likes to see more than hear.

In an article written by Saad (2012) entitled "Active Learning in Effective Teaching and Learning of Islamic Education", he explained one of the strategies in the implementation of active learning was a teacher must stimulate and awaken the pupils' interests in the subject. Hence, teachers must raise awareness and instil in the pupils that Islamic Education is not merely a subject to pass an exam, but it is essential to become a Muslim with perfect religion and character, loved by Allah and the community.

\section{Research Objective}

Generally this research is to survey the Integrity school pupils' perceptions on the aspect of interests towards the teaching of Islamic Education. This research also surveyed pupils' perceptions on the influence of teaching and learning Islamic Education on the practice of akhlak or moral values in their daily lives.

\section{Methodology}

This research utilised the quantitative survey research method. It aimed to obtain preliminary information on pupils' interests of one Integrity School on the teachings of Islamic Education. This research also explored pupils' perceptions on the impact of the teaching and learning of Islamic Education on the practice of moral values in their daily lives. 
The researcher used the purposive sampling method to collect data. As many as 33 pupils answered completely the distributed survey forms. According to Hague and Harris (1993), most researches accepted samples more than 30 and less 500 . Henceforth, the number of respondents were sufficient to obtain preliminary data.

To obtain the information needed, the researcher utilised questionnaires to survey the pupils' interests towards the teachings of Islamic Education and their perceptions on the teachers' practices. The researcher wanted to find out how far the teachers inculcated moral values in the pupils during the process of teaching and learning the Islamic Education. To determine the degree of reliability, a pilot study was carried out. The reliability coefficient of the instruments in measuring the pupils' interests in the Islamic Education teachers teaching was 0.837 , and the pupils' perceptions towards the teaching of Islamic Education was 0.852 . The overall mean value of each item in the questionnaire exceeded 0.80 . The acquired data was analysed and applied to the statistics method to obtain the required information by using the Statistical Package for the Social Science (SPSS) programme.

\section{Research Findings}

As many as 33 school pupils were involved in this preliminary research. They were pupils from an Integrity School between the ages of 15 and 17. The numbers were quite limited because the pupils were involved in school activities. However, the research was carried out smoothly with the help of a prison officer. The pupils answered the questions in the questionnaire with discipline. Before the pupils answered the questionnaire, the researchers gave an explanation on the purpose of the research and it's content to avoid any form of confusion and vagueness. The pupils completed the questionnaire within $20-30$ minutes.

\section{Pupils' Interests in the Teaching of Islamic Education}

The following are the findings related to the interests and attitudes towards the teaching of the Islamic Education. The statistical mean interpretation was utilized to interpret the findings of the mean scores as shown in Table 10.

Table 1: Interpretation of the Mean Scores

\begin{tabular}{|c|c|}
\hline Mean & Interpretation \\
\hline 1.0 to 2.3 & Disagree \\
\hline 2.4 to 3.7 & Least agree \\
\hline 3.8 to 5.0 & Agree \\
\hline \multicolumn{2}{|c|}{ Modified from Lendal (1997) }
\end{tabular}

Overall, the research findings showed the pupils' interests towards the teachings of Islamic Education was high (Table 1). Based on the results, the pupils agreed they were interested in the Islamic Education subject (mean = 4.43). The item which stated "I like to explore the religious knowledge" obtained a high level of agreement (mean=4.40). This was followed by the pupils agreement that their parents or guardians encouraged them to vigorously study Islamic Education (mean=4.37). In fact, the pupils agreed they were at a loss if they did not attend the 
INTERNATIONAL JOURNAL OF ACADEMIC RESEARCH IN PROGRESSIVE EDUCATION AND DEVELOPMENT

Vol. 8, No. 4, 2019, E-ISSN: 2226-6348 @ 2019 HRMARS

class. (mean=4.30). They also slightly disagreed with the opinion "Islamic Education is taught in class for leisure" (mean=3.73).

Table 2: Pupils' Interests in the Teaching of Islamic Education

\begin{tabular}{|c|c|c|c|}
\hline No & Statements & Mean & SD \\
\hline 1. & I am interested in the Islamic Education subject & 4.43 & .679 \\
\hline 2. & I like to deepen my knowledge in the religious field. & 4.40 & .675 \\
\hline 3. & I like to ask questions in class & 3.67 & .922 \\
\hline 4. & $\begin{array}{l}\text { If there is a personal problem, I like to complain to } \\
\text { the Islamic Education teacher. }\end{array}$ & 3.10 & 1.348 \\
\hline 5. & I get sleepy when the teacher enters the class. & 3.30 & 1.442 \\
\hline 6. & I like to recite the Al-Quran & 3.73 & 1.081 \\
\hline 7. & $\begin{array}{l}\text { I am interested when the teacher uses the latest } \\
\text { instructional materials (OHP or computer LCD) in } \\
\text { teaching, }\end{array}$ & 4.53 & .629 \\
\hline 8. & I often associate myself to the teacher's teaching & 3.80 & .997 \\
\hline 9. & $\begin{array}{l}\text { I feel the loss if I am unable to attend the Islamic } \\
\text { Education classes. }\end{array}$ & 4.30 & .952 \\
\hline 10. & $\begin{array}{l}\text { I feel uncomfortable during the Islamic Education } \\
\text { teaching sessions. }\end{array}$ & 4.07 & 1.081 \\
\hline 11. & The Islamic Education subject is boring. & 4.10 & 1.213 \\
\hline 12. & $\begin{array}{l}\text { The Islamic Education subject does not give me new } \\
\text { knowledge. }\end{array}$ & 4.10 & 1.155 \\
\hline 13. & $\begin{array}{l}\text { The teacher who interests me most is the Islamic } \\
\text { Education teacher }\end{array}$ & 3.80 & .925 \\
\hline 14. & $\begin{array}{l}\text { How the Islamic Education teacher teaches } \\
\text { stimulates my mind. }\end{array}$ & 4.10 & .712 \\
\hline
\end{tabular}


INTERNATIONAL JOURNAL OF ACADEMIC RESEARCH IN PROGRESSIVE EDUCATION AND DEVELOPMENT

Vol. 8, No. 4, 2019, E-ISSN: $2226-6348$ @ 2019 HRMARS

\begin{tabular}{|c|l|l|l|}
\hline 15 & $\begin{array}{l}\text { How the Islamic teacher teaches touches my } \\
\text { feelings (e.g. sense of realisation). }\end{array}$ & 4.27 & .740 \\
\hline 16. & $\begin{array}{l}\text { Mother/Father/Guardian encourages me to learn } \\
\text { the Islamic Education intently. }\end{array}$ & 4.37 & 1.033 \\
\hline 17. & $\begin{array}{l}\text { The learning time for Islamic Education is a relaxing } \\
\text { time in the class. }\end{array}$ & 3.73 & 1.285 \\
\hline 18. & I pay attention to the teacher's teachings. & 4.10 & .923 \\
\hline
\end{tabular}

The Pupils' Perceptions on the Influence of Teaching and Learning Islamic Education

This research was also to survey the perceptions of pupils' on the influence of the teaching and learning of Islamic Education on themselves and on the application of Islamic values in their lives. The results obtained showed the overall pupils' perceptions were at a high level as shown in Table 2 (overall mean=4.31). Pupils were found to give a high level of agreement (mean=4.71) on the statement, "the teaching of Islamic Education is very useful for my future". Similarly, items related to the pupils' confidence that the Islamic Education subject could improve their character also recorded a high average (mean=4.65). This was followed by the statement, "the teaching of Islamic Education gives guidance in my life" (mean=4.58).

It was clear the pupils' perceptions on the influence of the teaching and learning of Islamic Education on their moral values were positive. This is proven when the majority of pupils (mean=4.55) stated Islamic Education was not just for knowledge but also for the Islamic moral values and characteristics. They also stated, "I regret not paying attention during the teachings of Islamic Education before this" (mean=4.65). What was most important the pupils were found to have a sense of conviction when they agreed, " studying Islamic Education makes me not want to repeat my past mistakes" (mean=4.49).

On the other hand, the item which recorded the lowest mean was "the Islamic Education subject is considered as unimportant by my friends" (mean=3.55). However, the pupils were in a slight disagreement (mean=3.77) with the item which stated, "I did not receive compliments from my parents even though I got excellent results for Islamic Education". These findings clearly indicated friends and parents were main factors in influencing the practice of moral values in their lives through the teaching and learning of Islamic Education.

The results also showed there was a significant relationship between the pupils' interests in the teaching of Islamic Education and the influence of the teaching and learning Islamic Education on the practice of moral values in life $(r=0.516, p<0.01)$. This means when the pupils were interested in learning Islamic Education, it would directly influence the application of moral values in their lives. Generally, the research findings showed overall the pupils agreed they were interested in exploring Islamic knowledge and were comfortable in the Islamic Education class. Similarly in the context of the influence of teaching and learning Islamic Education on the practice of moral 
INTERNATIONAL JOURNAL OF ACADEMIC RESEARCH IN PROGRESSIVE EDUCATION AND DEVELOPMENT

Vol. 8, No. 4, 2019, E-ISSN: 2226-6348 @ 2019 HRMARS

values in their lives, pupils in the Integrity School agreed Islamic Education was useful, could give guidance, built character, as well as useful for their future career.

Table 3: Pupils' Perceptions on the Teaching of Islamic Education

\begin{tabular}{|l|l|l|l|}
\hline No & Statements & Mean & SD \\
\hline 1. & $\begin{array}{l}\text { I am confident the Islamic Education subject } \\
\text { can improve my character. }\end{array}$ & 4.65 & .551 \\
\hline 2. & $\begin{array}{l}\text { The Islamic Education subject is very useful for } \\
\text { my future. }\end{array}$ & 4.71 & .558 \\
\hline 3. & $\begin{array}{l}\text { The teaching of Islamic Education provides } \\
\text { guidance and guidelines in my life. }\end{array}$ & 4.58 & .620 \\
\hline 4. & $\begin{array}{l}\text { The Islamic Education subject is not able to build } \\
\text { good character. }\end{array}$ & 4.03 & 1.197 \\
\hline 5. & $\begin{array}{l}\text { The Islamic Education subject is not important } \\
\text { for my future career }\end{array}$ & 4.19 & 1.167 \\
\hline 6. & $\begin{array}{l}\text { I do not receive praises from my parents even } \\
\text { though I excelled in the Islamic Education } \\
\text { subject }\end{array}$ & 3.77 & 1.203 \\
\hline 7 & $\begin{array}{l}\text { The teaching of Islamic Education reminds me } \\
\text { to observe the five daily prayers. }\end{array}$ & 4.71 & .461 \\
\hline 8. & $\begin{array}{l}\text { The Islamic Education subject does not focus } \\
\text { just on knowledge but also on the aspects of } \\
\text { character and practice. }\end{array}$ & 4.55 & 1.624 \\
\hline 9. & $\begin{array}{l}\text { The teaching of Islamic Education is not special } \\
\text { compared to the teachings of other subjects. }\end{array}$ & 4.03 \\
\hline 10. & $\begin{array}{l}\text { The Islamic Education subject is considered } \\
\text { unimportant by other teachers. }\end{array}$ & 4.16 \\
\hline 11. & $\begin{array}{l}\text { The Islamic Education subject is considered } \\
\text { unimportant by my friends. }\end{array}$ & 3.55 & 1.080 \\
\hline 12. & $\begin{array}{l}\text { Studying Islamic education, makes me want not } \\
\text { to repeat past mistakes. }\end{array}$ & 4.39 & .919 \\
\hline 13. & $\begin{array}{l}\text { I regret for not paying attention to the teaching } \\
\text { of Islamic Education before. }\end{array}$ & 4.65 & .608 \\
\hline
\end{tabular}

The Relationship between the Islamic Education Teachers' Teaching Practices and Pupils' Interests and Attitudes

This study was also to identify whether there was a relationship between the Islamic Education teachers' teaching Practices and Pupils' Interests and Attitudes. To find the relationship between the two variables, the correlation analysis was utilised based on the correlation coefficients $(r)$ value according to Guilford (1967). 
Table 4: The Values of the Pearson Correlation Coefficient $r$ and Interpretations

\begin{tabular}{|l|l|}
\hline $\begin{array}{l}\text { The values of Correlation } \\
\text { coefficient } r\end{array}$ & Interpretation \\
\hline Less than 2.0 & Very low \\
\hline 0.21 to 0.40 & Low \\
\hline 0.41 to 0.70 & Moderate \\
\hline 0.71 to 0.90 & High \\
\hline 0.91 to 1.00 & Very High \\
\hline
\end{tabular}

Based on Table 5 below, it was found there was a significant relationship between the Islamic Education Teachers teaching practices and pupils' interests and attitudes. This means when pupils' are interested in teachers' teaching of the Islamic Education, they will then have positive attitudes towards the teaching of Islamic Education.

Table 5: The Relationship between Islamic Education Teachers' Teaching Practices and Pupils' Interests and Attitudes

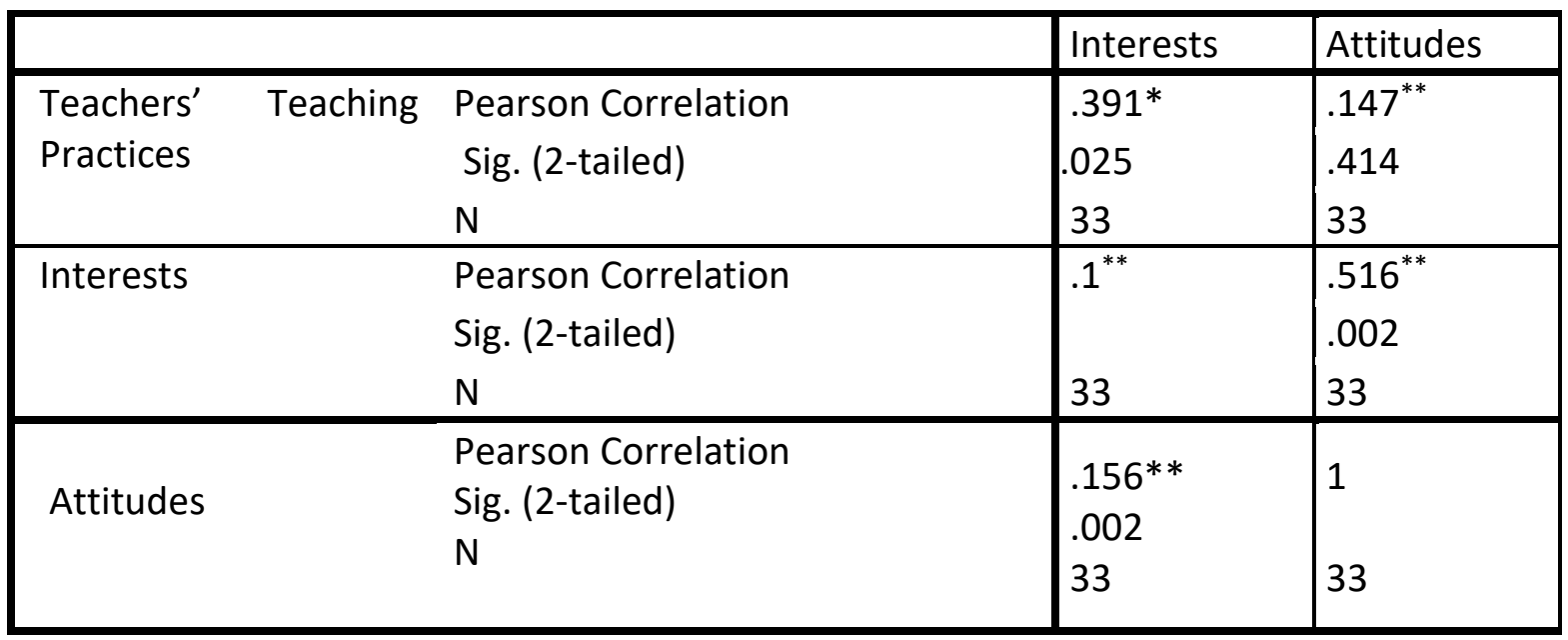

* Correlation is significant at the 0.05 level (2- tailed)

** Correlation is significant at the 0.01 level (2- tailed)

Based on Table 3, it was found there was a weak but significant relationship $(r=0.39, p<0.05)$ between teachers' teaching practices and pupils' interests. Similarly, there was a moderate significant relationship $(r=0.39, p<0.05)$ between teachers' teaching practices and pupils' attitudes.

\section{Discussion}

It is clear from the results, pupils in the Integrity School were interested in the Islamic Education subject. Even though they were pupils with disciplinary problems, in reality they liked religious 
knowledge. This was proven when pupils expressed that they liked to explore the Islamic religious knowledge. Hence, religious books need to be increased and always updated so it can benefit the pupils. Activities in the form of religious talks, usrah, dialogues, religious class and other similar activities must always be held to increase the pupils' Islamic knowledge and build conviction. This is because they agreed teachings of Islamic Education influenced them emotionally.

The school needs to provide infrastructures which are more conducive and more up-to-date teaching aid facilities so that the learning environment is fun and gives a positive impact to the pupils. This is because the pupils expressed interests in learning Islamic Education when the teachers used modern teaching tools.

The role of an Islamic Education teacher is not only as a mu'allim but also as a murabbi and muaddib must always approach and supervise the pupils' actions. Teachers must take the chance to play the role of the pupils' parents when they are in school. This issue is accentuated when fewer pupils complained their personal problems to the Islamic Education teacher. This situation must be improved so that pupils can also share their problems with the Islamic Education teacher so that they may receive guidance and advice which are condoned in Islamic teachings.

Pupils highly agreed on the prospects of Islamic Education for their future. Pupils agreed Islamic Education was very useful for their future. It can be said that, Islamic Education is important for their future careers. This is a positive indication because pupils not only had faith in the academic subjects, but also in Islamic Education and for it might offer them a bright future. They were clearly having positive perceptions on the influence of teaching and learning Islamic Education on the development and practice of moral values in their lives.

\section{Conclusion}

The findings showed that there is a significant relationship between the pupils' interest in the teaching of Islamic Education and the influence of the teaching and learning Islamic Education on the practice of moral values in life. They are comfortable in Islamic Education classes. They agreed that Islamic Education was beneficial, could give guidance and building character as well as useful for their future career. The findings also showed that there is a significant relationship between teachers' teaching practices and pupils' interest and the pupils' attitude. It is clear that when pupils are interested in teachers' teaching of the Islamic Education, they will then have positive attitude towards the teaching of Islamic Education. Based on the research discussion above, it clearly shows the efforts to offer Islamic Education to delinquents in Integrity Schools must be continued and it must also be enhanced from time to time. Islamic Education teachers must equip themselves with knowledge and skills especially psychological knowledge to approach and assist pupils. As human beings, they also require love and attention from adults. Hence, it is not only the obligation of fellow Islamic Education teachers but also other teachers' to improve and educate them. This is because without the power of faith and obedience to Allah SWT's orders, the efforts to educate and improve the pupils' morals will not succeed. It will be a loss if the Muslim generation is not provided with sufficient Islamic knowledge and a complete moral education which is based on Islamic moral values. The pupils are the generation who will 
INTERNATIONAL JOURNAL OF ACADEMIC RESEARCH IN PROGRESSIVE EDUCATION AND DEVELOPMENT

Vol. 8, No. 4, 2019, E-ISSN: 2226-6348 @ 2019 HRMARS

be future leaders to inherit the future of the ummah and country which are harmonious and outstanding on Earth and the Hereafter.

\section{Corresponding Author}

Asmawati Suhid is associate professor at the Faculty of Educational Studies, Universiti Putra Malaysia, 43400 UPM Serdang, Selangor Darul Ehsan, Malaysia. E-mail: asmawati@upm.edu.my

\section{References}

Ab. Halim, T. \& Rahimi, N. M. N. Y. (2010). Kaedah pengajaran dan pembelajaran Pendidikan Islam. Bangi: Penerbit Universiti Kebangsaan Malaysia.

Abd. Rahim, A. R. (2001). Nilai-nilai murni dalam pendidikan: Menghadapi perubahan dan cabaran alaf baru. Kuala Lumpur: Utusan Publications \& Distributors Sdn. Bhd.

Jamir, A. M. S. (2012). Pembelajaran aktif dalam pengajaran dan pembelajaran berkesan Pendidikan Islam. Kertas kerja yang dibentangkan di Persidangan Kebangsaan Pendidikan Islam Hotel Royal Bintang, Seremban, 3-6 Julai, 2012.

Agensi Antidadah Kebangsaan. (2011). Laporan Dadah Bulan September. Akses pada 30 Julai 2012 di www.adk.gov.my/laporan dadah.

Asyiqah, A. M. (2009). Meningkatkan minat pelajar dalam subjek Pendidikan Islam Bahagian Ibadah melalui simulasi. Kertas kerja yang dibentangkan di Kolokium DPLI, Palm Garden, Putrajaya, 26-27 Oktober 2009.

Asmawati, S. (2009). Pendidikan akhlak dan adab Islam. Kuala Lumpur: Utusan Publications \& Distributors Sdn. Bhd.

Asmawati, S, Fathiyah, M. F., Samsilah, R., Lukman, A. M. \& Mohd. Aderi, C. N. (2014). Private Islamic Primary School Teachers' Commitment in Human Capital Development in Malaysia. Mediterranean Journal of Social Sciences, Vol.5, 27, 766-773, 2014.

Asmawati, S. (2005). Persepsi guru dan pelajar di Selangor terhadap kesesuaian pengagihan komponen Adab dan Akhlak Islam dalam Pendidikan Islam Kurikulum Bersepadu Sekolah Menengah. Tesis Doktor Falsafah, Universiti Putra Malaysia.

Azhar, A. (2006). Strategi pembelajaran pengaturan kendiri Pendidikan Islam dan penghayatan akhlak pelajar sekolah menengah di Sarawak. Tesis doktor falsafah, Universiti Kebangsaan Malaysia.

Harian, B. (2010). Masalah salah laku disiplin pelajar masih terkawal. Akses pada 27 Julai 2012 di www.bharian.com.my/bharian/articles/

Chaplin, J. D. (1985). Dictionary of Psychology. New York: Dell Publishing Company.

Hague, P. \& Harris, P. (1993). Sampling and statistics. London: Kogan Page Limited.

Hanbal, I. (1995). Al-Musnad. Juz 3. Kaherah: Darul Fikr.

Azmi, K. J., \& Ab. Halim, T. (2012). Pendidikan Islam kaedah pengajaran dan pembelajaran. Skudai: Universiti Teknologi Malaysia.

Dewan, K. (2010). Edisi keempat. Dewan Bahasa dan Pustaka: Kuala Lumpur.

Khadijah, A., Rahim, M. S., Lukman, A. M., Anwar, A., Shah, S. T., \& Ellina, N. A. R. (2012). Kecerdasan sosial dan emosi guru cemerlang Pendidikan Islam dalam meningkatkan prestasi pelajar. Journal of Social Science and Humanities, 7(1), 94-104. 
Nazar, M. (2005). Pengantar psikologi: Satu pengenalan asas kepada jiwa dan tingkah laku manusia. Dewan Bahasa dan Pustaka: Kuala Lumpur.

Salma, M. R., Rohana, H. \& Amimudin, U. (2011). Menyelesaikan masalah pembangunan akhlak pelajar: Analisis penerapan kemahiran generik dalam amalan pendidikan. Journal of Edupress, 1(1), 223-229.

Sarimah, M., Kashfi, M. J., Ab. Halim, T. \& Kamarulzaman, AG. (2011). Kajian persepsi penghayatan akhlak Islam dalam kalangan pelajar sekolah menengah di Selangor. Global Journal Al-Thaqafah, 1(1), 71-77.

Muhammad, S. A. (1986). al-Mustatraf fi kulli fannin mustazraf. Beirut: Dar al-Kutub al-Ilmiah.

Shohana, H. (2010). Kesejahteraan dan kedamaian melalui pembangunan modal insan: kajian teks Hidayah Al-Salikin. In: Seminar Serantau Islam dan Kesejahteraan Sejagat, 24-25 Februari 2010, Universiti Islam Sultan Sharif Ali Brunei Darussalam.

Zulzana, Z., Mohamed, S. \& Roslina, A. T. (2011). Hubungan antara minat, sikap dan pencapaian pelajar dalam kursus CC301-Quantity Mesurement. Politeknik Port Dickson 